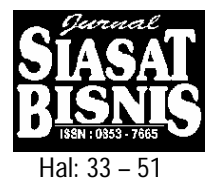

\title{
PENGUJIAN EFISIENSI PASAR BENTUK LEMAH DI BURSA SAHAM KUALA LUMPUR
}

\author{
D. Agus Harjito \\ Fakultas Ekonomi \\ Universitas Islam Indonesia
}

\begin{abstract}
The purpose of this study is to examine the weak-form of the efficient market hypothesis on the Kuala Lumpur Stock Exchange (KLSE). The weak form of the efficient market hypothesis asserts that the short-run future price movements of stock issue are approximately random in character: that is, there are independent of the past history of price movements. A market is efficient in the weak form sense if stock prices fully reflect the information implied by all past price movements. This study employ weekly closing prices of the 40 stocks selected from companies continuously listed on the second board of KLSE from the period July 1997 through December 2002. This period was separated into two sub-periods. The first sub-period is from July 1977 to December 1998 as the economic crisis period, and the second sub-period is from January 1999 to December 2002 as the post-crisis economic period. To examine the weak form efficient market hypothesis three models, i.e, serial correlations test, run test, and unit root test were used. The results showed that the weak form efficient market hypothesis is exhibited in the second board of Kuala Lumpur Stock Exchange during and after the economic crisis period as well.
\end{abstract}

\section{PENDAHULUAN}

Menurut Yong (1997), istilah pasar efisien pertama sekali digunakan dalam konteks pasar sekuritas oleh Fama, Fisher, Jensen dan Roll (1969). Mereka menyatakan bahwa pasar efisien adalah pasar yang membuat penyesuaian secara cepat terhadap informasi baru yang muncul. Selanjutnya Fama (1970) melanjutkan proses pembentukan resmi konsep efisiensi ini dalam istilah ekonomi dengan menyatakan bahwa pasar efisien sebagai suatu pasar yang menunjukkan keadaan harga yang senantiasa mencerminkan sepenuhnya informasi relevan yang tersedia. Kemudian Fama (1976) memperbaiki definisinya mengenai pasar efisien dengan mengatakan bahwa pasar efisien merupakan pasar yang menggunakan semua informasi secara benar. Pasar efisien bisa terjadi jika harga-harga berubah secara acak (random). Perubahan harga secara acak maksudnya seri perubahan harga tidak dipengaruhi oleh data harga waktu lalu, dan oleh karena itu seri perubahan harga masa lalu tidak bisa digunakan untuk menaksir perilaku harga waktu akan datang secara signifikan. Artinya, semua pergerakan harga dari waktu lalu, waktu sekarang dan waktu akan datang adalah bebas (independent). 
Ada dua asumsi model perubahan acak (Berkman, 1978). Pertama, harapan adalah rasional (rational expectation). Dalam proses pembuatan ramalan, peramal atau investor menggunakan semua informasi saat ini (current information) yang relevan. Harapan ini rasional jika informasi yang relevan dengan sekuritas bersangkutan dipertimbangkan oleh investor. Kedua, pasar modal adalah efisien. Asumsi ini merupakan dasar bagi model perubahan acak. Pasar modal adalah efisien jika informasi yang tersedia diserap kedalam harga saham saat ini dengan cara yang cepat dan tepat (quickly and accurately). Oleh karena informasi yang diterima berlaku secara acak dan harga berubah menurut informasi tersebut, maka hal ini memberi implikasi bahwa harga sekuritas bergerak atau berubah secara acak.

Haugen (2001) menerangkan bahwa ada empat ciri atau karakteristik pasar efisien. Pertama, harga sekuritas bertindak secara cepat (quickly) dan tepat (accurately) bila menerima informasi baru yang relevan. Kedua, perubahan hasil (return) saham yang diharapkan dari waktu ke waktu dihubungkan dengan tingkat bunga bebas risiko dan perubahan tingkat risiko premium atas sekuritas bersangkutan. Ketiga, kita tidak bisa membedakan antara investasi yang menguntungkan dengan investasi yang tidak menguntungkan untuk waktu akan datang berdasar ciri-ciri investasi saat ini atau waktu lalu. Keempat, jika kita memisahkan investor yang ahli dengan investor yang tidak ahli (tidak pakar), maka kita tidak dapat membuat perbedaan secara nyata diantara prestasi kedua kelompok investor tersebut.

Menurut Fama (1970), hipotesis pasar efisien dibagi ke dalam tiga bentuk yaitu pasar efisien bentuk lemah (weak-form efficiency), bentuk setengah kuat (semi strong-form efficiency) dan bentuk kuat (strong-form efficiency). Pembagian bentuk pasar efisien tersebut bergantung kepada informasi yang ada. Pertama, informasi harga waktu lalu yang informasi ini khususnya digunakan untuk mengetahui pasar efisien bentuk lemah. Kedua, informasi umum (public information) yang meliputi harga sekuritas waktu lalu dan informasi lain yang diperoleh dari pengumuman umum, seperti informasi mengenai perusahaan, industri, ekonomi negara, dan ekonomi dunia. Informasi umum ini digunakan untuk menguji hipotesis pasar efisien setengah kuat. Pasar saham adalah efisien dalam bentuk setengah kuat apabila harga saham merefleksikan secara serta merta terhadap informasi umum yang baru secara adil (fairly). Ketiga, informasi intern yaitu informasi internal perusahaan yang dimiliki oleh segelintir individu saja. Contohnya yaitu informasi pribadi (private information), informasi sampingan (inside information) dan informasi monopolistik (monopolistic information). Informasi intern ini terutama digunakan untuk menguji pasar efisien bentuk kuat yang semua informasi, baik informasi 
masa lalu, informasi umum maupun informasi intern, telah dicerminkan dalam harga saham.

Secara spesifik, penelitian pasar efisien bentuk lemah ini telah banyak dilakukan oleh para penyelidik pada b erbagai pasar modal, termasuk pasar modal Malaysia (Bursa Saham Kuala Lumpur). Untuk mengkaji hipotesis pasar efisien bentuk lemah dalam suatu pasar saham bisa digunakan tes-tes seperti tes korelasi seri (serial correlation test), tes run (run test), tes simulasi (simulation test), tes filter (filter rule test), dan tes taburan normal, tes akar unit (unit root test) dan analisis spektral (Yong, 1997).

\section{TUJUAN PENELITIAN DAN HIPOTESIS}

Suatu pasar saham adalah efisien dalam bentuk lemah jika harga saat ini (current price) mencerminkan secara penuh semua informasi harga waktu lalu dan perubahan harga dari waktu ke waktu adalah acak. Harga saham waktu lalu tidak dapat digunakan oleh investor untuk memperoleh untung lebih dari pasar (abnormal return). Penelitian ini bertujuan untuk menguji terwujudnya efisien pasar bentuk lemah di Papan Kedua (second board) Bursa Saham Kuala Lumpur, karena sebelum ini belum ada kajian yang dibuat terhadap pasar tersebut. Kajian-kajian sebelum ini terutama dilakukan pada papan utama (main board) saja. Periode kajian adalah dari bulan Juli 1997 hingga Desember 2002. Berdasarkan pada tujuan penelitian tersebut, tiga hipotesis nol akan diuji yaitu:
$\mathrm{H}_{01}$ : Koefisien korelasi pada lag 1, lag 2, lag 3, dan lag 4 dari perubahan harga saham yang terdaftar di Papan Kedua BSKL sama dengan nol.
$\mathrm{H}_{02}$ : Perubahan harga dari waktu ke waktu bagi saham yang terdaftar di Papan Kedua BSKL bersifat acak.
$\mathrm{H}_{03}$ : Perubahan harga saham di Papan Kedua BSKL bersifat fluktuatif (unstationary).

Penelitian ini akan dimulai dengan perbincangan mengenai kajian penelitian masa lalu tentang hipotesis pasar efisien. Kemudian akan diikuti dengan perbincangan mengenai data yang akan digunakan dan model yang akan dibentuk untuk melihat efisiensi pasar modal. Bagian berikutnya akan melaporkan hasil tes korelasi seri, tes run dan tes akar unit. Kesimpulan dan implikasi akan diberikan pada bagian akhir laporan ini. 


\section{KAJIAN PENELITIAN TERDAHULU}

Penelitian pasar efisien yang pertama oleh Fama, Fisher, Jensen dan Roll (1969) menggunakan data bulanan untuk menguji reaksi harga saham terhadap pengumuman pemecahan saham yang terjadi di New York antara tahun 1929 hingga 1959. Pemecahan saham yang dilakukan oleh emiten dihubungkan dengan kenaikan dan penurunan pembayaran dividen. Sebanyak 80 persen kasus pemecahan saham diikuti oleh kenaikan dividen. Kenaikan dividen ini dianggap sebagai tanda positip bagi investor yang direfleksikan pada kenaikan harga saham.

Fama dan Blume (1966) telah melakukan tes terhadap 30 saham Dow Jones dengan menggunakan tes filter (filter rule test). Tes filter ini digunakan untuk melakukan tes langsung terhadap strategi perdagangan yang secara khusus atau dikatakan sebagai strategi beli dan pegang. Fama dan Blume mendapati bahwa pada filter 0.5 persen, strategi perdagangan memberikan return yang lebih dari strategi beli dan pegang. Hasil penelitian ini mempunyai implikasi bahwa pasar adalah efisien karena return yang diperoleh tidak melebihi return pasar.

Satu penelitian perilaku harga saham menggunakan tes korelasi seri telah dilakukan oleh D'Ambrosio (1980) terhadap indeks-indeks saham di Bursa Saham Singapura. Hasil penelitian menunjukkan bahwa sektor hotel, industri dan timah memberikan nilai korelasi yang tinggi atau signifikan. Ini Artinya perubahan harga bagi sektor hotel, industri dan timah adalah berkaitan dengan arah perubahan waktu lalu. Sedangkan bagi sektor-sektor keuangan, tanah dan karet mempunyai koefisien korelasi yang kecil, yang maknanya tidak ada hubungan yang signifikan antara perubahan harga waktu $t$ dengan waktu t+1. Ini juga bermakna bahwa perubahan harga adalah acak.

Penelitian perubahan acak harga saham dilakukan pula oleh Dockery, Vergari dan Vergari (2001) terhadap data bulanan selama tahun 1988 hingga 1994 terhadap saham individual pada Bursa Saham Athena (Athens Stock Exchange). Mereka menggunakan tes varian rasio untuk mengetahui adanya rata-rata ketergantungan antara perubahan harga saham. Hasil penelitian menunjukkan bahwa perilaku perubahan sahamsaham di Bursa Saham Athena telah mengikuti perubahan acak. Hal ini mendukung hipotesis pasar efisien bentuk lemah.

Ojah dan Karemera (1999) melakukan tes hipotesis pasar efisien bentuk lemah di bursa-bursa saham Amerika Latin (Argentina, Brazil, Chile dan Mexico). Mereka menggunakan multiple variance-ratio dan autoregressive fractionally integrated moving-average tests untuk menguji perilaku harga saham di pasar tersebut antara tahun 1987 hingga 1997. Hasil tes menunjukkan bahwa perubahan harga saham-saham di Amerika Latin mengikuti perubahan acak sehingga mendukung pasar efisien bentuk lemah. 
Kleiman, Payne dan Sahu (2002) menggunakan tes run untuk menguji pasar efisien bentuk lemah pada international commercial real estate. Tes run mendukung bahwa pasar real estate komersial internasional mengikuti hipotesis pasar efisien bentuk lemah. Hal ini konsisten dengan penemuan mereka mengenai perilaku perubahan acak dari saham-saham dengan menggunakan tes akar unit dan tes rasio varian.

Penelitian efisiensi pasar bentuk lemah di pasar modal Malaysia telah banyak dilakukan oleh para peneliti, terutama terhadap BSKL papan utama (main board). Pertama, penelitian dilakukan oleh Cheng (1978). Beliau menggunakan tes run dan korelasi seri untuk menguji perilaku harga 12 saham industri dari tahun 1973 hingga 1975. Hasil tes menunjukkan bahwa perilaku harga saham bersangkutan tidak mengikuti perubahan acak (random walk). Penelitian Cheng ini tidak menunjukkan pasar saham yang efisien. Ini karena waktu penelitian yang sempit dan sampel yang tidak mewakili sehingga tidak bisa digeneralisir.

Penelitian Lim (1981) memakai tigapuluh saham yang aktif diperdagangkan dan enam indeks sektoral untuk periode bulan Juni 1974 hingga Juni 1980. Beliau menggunakan tes konvensional, yakni tes korelasi seri dan tes run. Hasil tes meunjukkan bahwa beberapa sampel mempunyai perilaku yang acak. Oleh karena itu hasil penelitian menunjukkan bahwa Bursa Saham Kuala Lumpur adalah efisien dalam bentuk lemah khususnya untuk saham-saham yang aktif diperdagangkan.

Nassir (1983) menggunakan data bulanan dari 101 saham yang aktif diperdagangkan selama bulan Januari 1975 hingga Juni 1980. Hasil penelitian mendukung hipotesis pasar efisien bentuk lemah di BSKL. Sedangkan Barnes (1986) memakai data harga saham penutupan bulanan dari 30 saham yang dipilih dari bulan Juni 1975 hingga Juni 1980 untuk menguji efisiensi pasar bentuk lemah. Hasil kajian menggunakan perbedaan logaritma natural (natural logarithm) menunjukkan bahwa BSKL efisien dalam bentuk lemah.

Yong (1987) menggunakan harga penutup mingguan 30 saham yang dipilih secara acak dari perusahaan-perusahaan yang terdaftar pada Indeks Industri Bursa Saham Kuala Lumpur bulan Januari 1977 hingga Mei 1985. Penelitian ditujukan untuk menguji kebebasan (independence) perubahan harga saham dengan menggunakan tes korelasi seri dan menguji keacakan perubahan harga saham dengan menggunakan tes run. Hasil tes korelasi seri menunjukkan bahwa terdapat 12 dari 30 saham yang mempunyai koefisien korelasi yang signifikan antara harga waktu lalu dengan harga waktu akan datang pada lag 1. Dari tes inipun terdapat duapuluh sahamsaham yang menunjukkan koefisien korelasi negatif. Adapun hasil tes run menunjukkan bahwa terdapat 14 dari 30 saham memiliki perbedaan yang signifikan antara run yang riil (real run) dengan run yang diharapkan 
(expected run). Ini artinya sebanyak 46,67 persen dari saham-saham di Malaysia menunjukkan kelainan dari perubahan acak sehingga perubahan harga saham adalah menurut suatu aliran tertentu. Ini maknanya investor bisa mendapati return saham yang melebihi return rata-rata pasar.

\section{DATA DAN METODOLOGI}

Dalam penelitian ini akan digunakan data harga (price index) penutupan mingguan dari 40 saham yang terdaftar di Papan Kedua (second board) dan indeks komposit Papan Kedua Bursa Saham Kuala Lumpur. Pemilihan data harga saham mingguan dimaksudkan untuk menghindari kekosongan data apabila menggunakan data harian. Sahamsaham tersebut adalah diperdagangkan dari bulan Juli 1997 hingga 31 Desember 2002. Periode waktu tersebut akan dibagi menjadi dua periode yaitu dari bulan Juli 1997 hingga Desember 1998 sebagai periode I (periode waktu selama krisis ekonomi) dan dari Januari 1999 hingga Desember 2002 merupakan periode II (periode waktu setelah krisis ekonomi). Pembagian kedua periode ini didasarkan bahwa krisis ekonomi mulai Juli 1997 dan berakhir hingga Desember 1998.

Metode persentase digunakan untuk memilih sampel dari sahamsaham yang terdaftar di Papan Kedua BSKL. Pada bulan Juli 1997 telah terdaftar 242 saham di Papan Kedua. Tidak semua saham bersangkutan terdaftar terus hingga 31 Desember 2002 karena saham yang telah memenuhi persyaratan tertentu atau prestasinya meningkat akan didaftarkan di Papan Utama (main board). Oleh karena itu sebanyak 40 saham yang menjadi sampel pada penelitian ini adalah saham-saham yang terdaftar secara terus menerus di Papan Kedua sejak bulan Juli 1997 hingga Desember 2002. Saham yang dipakai sebagai sampel dipilih dari 4 sektor yang ada di Papan Kedua, yaitu sektor barang konsumsi (consumer products) sebanyak 7 saham, sektor barang industri (industrial products) sebanyak 19 saham, sektor bangunan (construction) sebanyak 4 saham, sektor perdagangan dan pelayanan (trading/service) sebanyak 10 saham.

\section{METODE ANALISIS DATA}

Data harga mingguan saham-saham yang dipilih dan indeks komposit papan kedua diperoleh dari Datastream, Daily Diary dan majalah bulanan Investors Digest yang diterbitkan oleh BSKL. Kesemua data harga saham dan indeks komposit yang akan dikaji lebih dahulu dihitung perubahannya dengan menggunakan formula berikut: 


$$
\begin{aligned}
Z_{t}= & \frac{P_{t}-P_{t-1}}{P_{t-1}} \\
\text { dengan } & Z_{t}=\text { perubahan harga saham pada waktu } t ; \\
& P_{t}=\text { harga saham pada waktu } t ; \\
& P_{t-1}=\text { harga saham pada waktu } t-1 .
\end{aligned}
$$

\section{Tes Korelasi Seri (Serial Correlation Test)}

Hipotesis yang diuji dalam tes ini bahwa koefisien korelasi antara perubahan harga mingguan secara berturutan pada lag $\mathrm{j}(\mathrm{j}=1,2,3,4)$ adalah nol selama waktu penelitian. Penelitian ini menggunakan lag hingga 4 minggu dengan justifikasi bahwa pola perubahan harga saham bisa dilihat pada periode satu bulan (1 bulan sama dengan 4 minggu). Untuk menguji hipotesis tersebut, return saham periode $t$ diregres dengan return pada periode $\mathrm{t}-\mathrm{j}$ ( $\mathrm{j}$ adalah interval lag). Penghitungan koefisien korelasi seri digunakan formula (Yong, 1988):

$$
r j=\frac{\operatorname{Cov}\left(Z_{t}, Z_{t}+j\right)}{\operatorname{Variance}\left(Z_{t}\right)}
$$

dengan

$r_{j} \quad=$ koefisien korelasi sampel untuk lag $j$;

$\operatorname{Cov}\left(Z_{t}, Z_{t+j}\right)=$ kovarian return antara $Z_{t}$ dan $Z_{t+j} ;$

Variance $\left(Z_{t}\right)=$ varian return untuk periode waktu $(t, t+j)$.

Jika nilai $r_{j}$ mendekati 0 dan secara statistik signifikan, ini menunjukkan bahwa return antara periode waktu $t$ dan $t+j$ adalah tidak saling tergantung (independent). Untuk jumlah sampel besar, koefisien korelasi akan mendekati normal dengan deviasi standar:

$$
\mathrm{S}\left(\mathrm{r}_{\mathrm{k}}\right)=\left[\frac{1}{\sqrt{\mathrm{N}-\mathrm{k}}}\right]
$$

dengan $\mathrm{S}\left(\mathrm{r}_{\mathrm{k}}\right)=$ deviasi standar; $\mathrm{k}=1,2, \ldots . \operatorname{lag} \mathrm{j}<\mathrm{N}$, dan $\mathrm{N}$ adalah jumlah sampel.

Hipotesis pasar efisien mengharapkan bahwa hipotesis nol akan diterima (koefisien korelasi tidak berbeda dengan nol) dengan menggunakan uji Box-Pierce Q-statistik:

$$
\mathrm{Q}=\mathrm{N} \sum_{\mathrm{j}=1}^{\mathrm{k}} \mathrm{r}_{\mathrm{j}}^{2}
$$


dengan $\mathrm{N}$ adalah jumlah sampel dan $\mathrm{k}$ adalah derajat kebebasan (degree of freedom) dalam uji kai kuadrat (chi square).

\section{Tes Run (Run Test)}

Tes run (tes larian) digunakan untuk mengatasi tes korelasi dengan Q-statistik yang hasilnya didominasi oleh nilai ekstrim hasil korelasi yang terlalu besar atau terlalu kecil. Jumlah run (larian) yang diharapkan dihitung dengan formula sebagai berikut:

$$
E(R)=\frac{\left[N(N+1)-N \sum_{j=1}^{k} n_{i}^{2}\right]}{N},
$$

dengan $\mathrm{n}$ adalah persentase perubahan setiap tanda dan $\mathrm{N}$ adalah jumlah total dari perubahan harga. Deviasi standar dari tes run (Sr) dihitung sebagai berikut:

$$
\mathrm{S}(\mathrm{r})=\left[\frac{\sum_{\mathrm{i}=1}^{3} \mathrm{n}_{i}^{2}\left[\sum_{\mathrm{i}=1}^{3} \mathrm{n}_{\mathrm{i}}^{2}+\mathrm{N}(\mathrm{N}+1)-2 \mathrm{~N} \sum_{\mathrm{i}=1}^{3} \mathrm{n}_{\mathrm{i}}^{3}-\mathrm{N}^{3}\right]}{\mathrm{N}^{2}(\mathrm{~N}-1)}\right]^{/ 2}
$$

Hipotesis nol yang menyatakan bahwa persentase perubahan harga saham adalah acak diuji dengan formula:

$$
\mathrm{Z}=\frac{\mathrm{R}-\mathrm{E}(\mathrm{R}) \pm \frac{1}{2}}{\mathrm{~S}(\mathrm{r})}
$$

di mana:

$\mathrm{R} \quad=$ jumlah run riil (observasi);

$E(R)=$ jumlah run yang diharapkan;

$S(r)$ = jumlah deviasi standar run dari sampel, dan angka $1 / 2$ adalah faktor koreksi untuk penyesuaian tanda.

Penyesuaian ini mempunyai nilai plus ( + ) jika $R \leq E(R)$ dan minus (-) jika terjadi sebaliknya. Hipotesis nol yang menyatakan bahwa persentase perubahan harga saham adalah acak diterima jika nilai Z: -1.96 $\leq \mathrm{Z} \leq 1.96$ pada tingkat signifikansi $5 \%$, atau $-2.576 \leq \mathrm{Z} \leq 2.576$ pada tingkat signifikansi $1 \%$. 


\section{Tes Akar Unit (Unit Root Test)}

Nasir dan Arif (1993) menyatakan bahwa aliran dan tren waktu (drift and time-trend) dalam analisis rangkaian waktu bisa diuji menggunakan tes akar unit. Tes ini menguji fluktuasi aliran perubahan harga saham. Menurut mereka tes ini menghasilkan kesimpulan yang konsisten dan tidak bias dengan analisis korelasi serial. Model autoregresi akar unit yang disederhanakan adalah:

$$
Y_{t}=a+b Y_{t-1}+u_{t}
$$

dengan $Y_{t}=$ harga saham mingguan pada waktu $t=1 \ldots . . T ; a, b=$ koefisen regresi; dan $u_{t}=$ residual. Pengujian tes akar unit ini menggunakan uji tstatistik dengan nilai kritikal Dicky-Fuller untuk menerima atau menolak hipotesis nol.

\section{HASIL PENELITIAN}

Jumlah dan persentase saham-saham yang digunakan dalam penelitian ini bisa dilihat pada tabel 1. Dari 40 saham, 17.5 persen merupakan saham barang konsumsi, 47.5 persen saham barang industri, 10 persen saham bangunan, dan 25 persen saham perdagangan.

Tabel 1. Jumlah dan persentase saham untuk setiap sektor

\begin{tabular}{lcc}
\hline \multicolumn{1}{c}{ Sektor } & Jumlah saham & $\begin{array}{c}\text { Persentase } \\
\text { saham }\end{array}$ \\
\hline Barangkonsumsi (consumer products) & 7 & 17.5 \\
Barang industri (industrial products) & 19 & 47.5 \\
Bangunan (construction) & 4 & 10.0 \\
Perdagangan (trading) & 10 & 25.0 \\
\hline Jumlah & 40 & 100.0 \\
\hline
\end{tabular}

\section{Hasil Tes Korelasi Seri dan Statistik-Q}

Tes korelasi seri dilakukan untuk lag 1 hingga 4 baik untuk periode I (selama krisis) maupun periode II (setelah krisis). Dalam tabel 2 ditunjukkan jumlah dan persentase saham yang hasil tes korelasi serinya signifikan berbeda dengan nol pada tingkat signifikansi 5 persen dan 1 persen untuk setiap sektor untuk periode I dan periode II. 
Tabel 2. Jumlah dan persentase saham yang korelasi serinya signifikan untuk lag 1hingga lag 4 pada tingkat signifikansi 5 dan 1 persen untuk periode I dan II

\begin{tabular}{|c|c|c|c|c|c|c|c|c|c|c|c|c|c|c|c|c|}
\hline \multirow[t]{3}{*}{ Sektor } & \multicolumn{8}{|c|}{ Periode I } & \multicolumn{8}{|c|}{ Periode II } \\
\hline & \multicolumn{2}{|c|}{$\operatorname{Lag} 1$} & \multicolumn{2}{|c|}{$\operatorname{Lag} 2$} & \multicolumn{2}{|c|}{$\operatorname{Lag} 3$} & \multicolumn{2}{|c|}{$\operatorname{Lag} 4$} & \multicolumn{2}{|c|}{$\operatorname{Lag} 1$} & \multicolumn{2}{|c|}{$\operatorname{Lag} 2$} & \multicolumn{2}{|c|}{$\operatorname{Lag} 3$} & \multicolumn{2}{|c|}{$\operatorname{Lag} 4$} \\
\hline & $\#$ & $\%$ & \# & $\%$ & \# & $\%$ & \# & $\%$ & \# & $\%$ & \# & $\%$ & \# & $\%$ & \# & $\%$ \\
\hline \multirow{2}{*}{ Barang Konsumsi } & 0 & 0 & 0 & 0 & 0 & 0 & 0 & 0 & 1 & 14 & 1 & 14 & 0 & 0 & 0 & 0 \\
\hline & 0 & 0 & 0 & 0 & 0 & 0 & 0 & 0 & 1 & 14 & 1 & 14 & 1 & 14 & 1 & 14 \\
\hline \multirow{2}{*}{ Barang Industri } & 0 & 0 & 2 & 11 & 2 & 11 & 2 & 11 & 2 & 11 & 1 & 5 & 1 & 5 & 1 & 5 \\
\hline & 0 & 0 & 0 & 0 & 0 & 0 & 0 & 0 & 0 & 0 & 1 & 5 & 1 & 5 & 1 & 5 \\
\hline \multirow{2}{*}{ Bangunan } & 0 & 0 & 0 & 0 & 0 & 0 & 0 & 0 & 0 & 0 & 0 & 0 & 0 & 0 & 0 & 0 \\
\hline & 0 & 0 & 0 & 0 & 0 & 0 & 0 & 0 & 1 & 25 & 1 & 25 & 1 & 25 & 1 & 25 \\
\hline \multirow{2}{*}{ Perdagangan } & 0 & 0 & 0 & 0 & 0 & 0 & 0 & 0 & 0 & 0 & 0 & 0 & 0 & 0 & 0 & 0 \\
\hline & 0 & 0 & 0 & 0 & 0 & 0 & 0 & 0 & 1 & 10 & 1 & 10 & 1 & 10 & 1 & 10 \\
\hline
\end{tabular}

Catatan: Jumlah dan persentase korelasi seri baris pertama untuk tingkat signifikansi 5 persen dan baris kedua untuk tingkat signifikansi $1 \%$.

Jika dilihat dari hasil korelasi seri saham-saham terpilih, maka nampak bahwa pada periode I (periode selama terjadi krisis ekonomi) ada 2 saham (atau 11 persen) yang mempunyai koefisien korelasi seri yang signifikan berbeda dengan nol pada tingkat signifikansi 5 persen untuk lag 2, lat 3, dan lag 4 yaitu saham dari sektor barang industri. Sedangkan tidak ada satupun saham yang signifikan pada tingkat signifikansi 1 persen.

Pada periode II (periode setelah krisis ekonomi), 14 persen dari saham barang konsumsi mempunyai koefisien korelasi seri yang signifikan pada lag 1 dan lag 2 untuk tingkat signifikansi 5 persen. Sedangkan pada tingkat signifikansi 1 persen, 14 persen dari saham barang konsumsi mempunyai korelasi seri yang signifikan pada lag-lag 1, 2, 3, dan 4.

Pada tingkat signifikansi 5 persen, 11 persen dari saham barang industri mempunyai korelasi seri yang signifikan pada lag 1 , dan 5 persen pada lag-lag 2, 3, dan 4. Sedangkan pada tingkat signifikansi 1 persen, 5 persen dari saham barang industri mempunyai koefisien korelasi seri yang signifikan pada lag-lag 2, 3, dan 4.

Pada periode II tidak ada korelasi seri yang signifikan berbeda dengan nol untuk sektor bangunan dan perdagangan pada tingkat signifikansi 5 persen. Pada tingkat signifikansi 1 persen, 25 persen dari saham bangunan mempunyai korelasi seri yang signifikan pada lag 1, lag 2 , lag 3, dan lag 4. Sedangkan pada tingkat signifikansi 1 persen pula, 10 persen dari saham perdagangan mempunyai korelasi seri yang signifikan pada lag-lag 1, 2, 3, dan 4.

Tabel 3 menunjukkan jumlah dan persentase saham untuk setiap sektor yang mempunyai koefisien korelasi keseluruhan (ditunjukkan oleh statistik-Q) yang signifikan. Korelasi seri secara keseluruhan dihitung 
signifikansinya untuk lag 1 hingga lag 4. Korelasi adalah signifikan jika nilai statistik-Q lebih besar dari nilai kritis kai kuadrat sebesar 9.488 untuk tingkat signifikansi 5 persen ataupun jika nilai statistik-Q tersebut melebihi 13.277 pada tingkat signifikansi 1 persen dengan 4 derajat kebebasan.

Pada tingkat signifikansi 5 persen selama periode I, 11 persen dari saham barang industri mempunyai korelasi seri keseluruhan yang signifikan. Tidak terdapat korelasi seri yang signifikan untuk saham-saham sektor lainnya. Pada tingkat signifikansi 1 persen tiada satupun saham mempunyai korelasi seri keseluruhan yang signifikan.

Pada tingkat signifikansi 5 persen selama periode II, 5 persen dari saham barang industri mempunyai korelasi seri keseluruhan yang signifikan. Tidak terdapat korelasi seri yang signifikan untuk saham-saham sektor lainnya. Pada tingkat signifikansi 1 persen, 14 persen dari saham barang konsumsi mempunyai korelasi seri keseluruhan yang signifikan, 5 persen untuk saham barang industri, 25 persen untuk saham bangunan, dan 10 persen untuk saham perdagangan.

Tabel 3. Jumlah dan persentase saham yang korelasi serinya secara keseluruhan signifikan pada tingkat signifikansi 5 dan 1 persen untuk periode I dan II

\begin{tabular}{|c|c|c|c|c|c|c|c|c|}
\hline \multirow{3}{*}{ Sektor } & \multicolumn{4}{|c|}{ Periode I } & \multicolumn{4}{|c|}{ Periode II } \\
\hline & \multicolumn{2}{|c|}{ Tingkat 5\% } & \multicolumn{2}{|c|}{ Tingkat $1 \%$} & \multicolumn{2}{|c|}{ Tingkat 5\% } & \multicolumn{2}{|c|}{ Tingkat $1 \%$} \\
\hline & \# & $\%$ & \# & $\%$ & \# & $\%$ & \# & $\%$ \\
\hline Barang Konsumsi & 0 & 0 & 0 & 0 & 0 & 0 & 1 & 14 \\
\hline Barang Industri & 2 & 11 & 0 & 0 & 1 & 5 & 1 & 5 \\
\hline Bangunan & 0 & 0 & 0 & 0 & 0 & 0 & 1 & 25 \\
\hline Perdagangan & 0 & 0 & 0 & 0 & 0 & 0 & 1 & 10 \\
\hline
\end{tabular}

Tabel 4 menunjukkan korelasi seri atas 40 saham papan kedua BSKL terpilih untuk periode I dan II. Untuk periode I, dua dari 40 saham tersebut menunjukkan koefisien korelasi yang signifikan pada lag 2, lag 3, dan lag 4 pada tingkat signifikansi 5 persen. Kedua saham tersebut adalah saham Kossan dan saham Hil. Sedangkan koefisien korelasi seri indeks komposit papan kedua BSKL berbeda dengan nol secara signifikan pada tingkat signifikansi 1 persen untuk lag 3 dan lag 4 .

Pada periode II ditunjukkan bahwa 4 saham mempunyai koefisien korelasi seri yang signifikan pada tingkat signifikansi 5 persen, yaitu saham Pohmay dan saham Poly pada lag 1 dan 2, saham KOA pada lag 3 dan 4, dan saham Lysaght pada lag 1. Sedangkan 3 saham mempunyai koefisien korelasi seri signifikan pada tingkat signifikansi 1 persen untuk lag 1, 2, 3, dan 4, yaitu saham Tcguan, saham YCS, dan saham Suiwah. Saham Lysaght signifikan pada lag 2, 3, dan 4. 
Tabel 4. Hasil tes korelasi seri lag 1 hingga lag 4 untuk periode I dan II

\begin{tabular}{|c|c|c|c|c|c|c|c|c|c|c|}
\hline \multirow[t]{2}{*}{ Saham } & \multicolumn{4}{|c|}{ Periode I $(n=78)$} & \multicolumn{3}{|c|}{ Periode II $(n=207)$} & \multicolumn{3}{|c|}{ Statistik-Q } \\
\hline & $\operatorname{Lag} 1$ & $\operatorname{Lag} 2$ & $\operatorname{Lag} 3$ & $\operatorname{Lag} 4$ & $\operatorname{Lag} 1$ & $\operatorname{Lag} 2$ & $\operatorname{Lag} 3$ & $\operatorname{Lag} 4$ & P.I & P- II \\
\hline Chewaah & 0.10 & 0.00 & 0.17 & -0.01 & 0.09 & 0.04 & 0.09 & -0.02 & 2.97 & 3.66 \\
\hline Hingyap & -0.04 & 0.03 & 0.08 & 0.31 & 0.01 & 0.02 & -0.02 & -0.11 & 8.75 & 2.67 \\
\hline Bonia & 0.10 & 0.01 & 0.17 & -0.11 & 0.13 & -0.02 & -0.03 & 0.01 & 4.15 & 3.95 \\
\hline Pohmay & 0.07 & -0.09 & 0.13 & 0.09 & $-0.15^{\star}$ & $0.09 *$ & 0.02 & -0.01 & 3.02 & 6.48 \\
\hline Rex & 0.04 & 0.13 & 0.08 & 0.11 & -0.06 & -0.05 & 0.00 & -0.07 & 3.06 & 2.27 \\
\hline Sinmah & 0.20 & 0.09 & 0.09 & 0.18 & 0.08 & -0.01 & 0.02 & 0.07 & 7.32 & 2.56 \\
\hline Tcguan & 0.24 & 0.00 & 0.16 & 0.11 & $-0.22^{\star \star}$ & $0.16^{* *}$ & -0.07 ** & 0.09 ** & 7.65 & $16.49 \mathrm{~b}$ \\
\hline Ajiya & -0.01 & 0.01 & 0.17 & 0.09 & 0.00 & 0.05 & -0.13 & -0.09 & 3.07 & 5.51 \\
\hline Belton & 0.11 & -0.10 & 0.19 & 0.18 & 0.06 & -0.05 & 0.02 & 0.02 & 7.55 & 1.29 \\
\hline Big & 0.08 & 0.06 & 0.19 & 0.07 & -0.04 & 0.01 & -0.09 & -0.08 & 4.16 & 3.73 \\
\hline Bright & -0.03 & 0.12 & 0.10 & 0.10 & 0.01 & 0.00 & -0.06 & 0.05 & 2.74 & 1.12 \\
\hline Daiboci & 0.24 & -0.04 & 0.06 & 0.14 & -0.07 & 0.08 & -0.11 & -0.02 & 6.50 & 4.97 \\
\hline Pahanco & 0.01 & -0.03 & 0.16 & 0.04 & 0.09 & -0.01 & -0.13 & -0.01 & 2.40 & 5.31 \\
\hline Harves & 0.02 & -0.04 & 0.08 & 0.18 & -0.06 & -0.14 & -0.09 & 0.05 & 3.41 & 7.23 \\
\hline KKB & 0.10 & -0.20 & 0.03 & 0.15 & -0.12 & 0.02 & -0.14 & 0.07 & 5.89 & 8.32 \\
\hline KOA & 0.10 & -0.14 & 0.12 & 0.05 & -0.01 & 0.06 & $-0.22^{*}$ & $-0.08^{*}$ & 3.56 & $12.49^{a}$ \\
\hline Kossan & -0.16 & $0.33^{\star}$ & $-0.01^{*}$ & $0.10^{*}$ & -0.09 & -0.01 & -0.07 & -0.05 & $11.36^{a}$ & 3.28 \\
\hline Latex-X & 0.22 & 0.00 & 0.12 & 0.05 & 0.05 & 0.11 & -0.04 & 0.03 & 5.08 & 3.69 \\
\hline Lsteel & -0.07 & 0.04 & 0.28 & 0.05 & -0.08 & -0.05 & 0.08 & -0.09 & 6.94 & 5.39 \\
\hline Lysaght & 0.19 & -0.07 & 0.20 & 0.09 & $-0.17^{*}$ & $0.15^{\star \star}$ & $-0.17^{\text {** }}$ & $0.05^{\star \star}$ & 7.12 & $17.07^{b}$ \\
\hline Trutech & 0.12 & -0.02 & 0.15 & 0.06 & -0.01 & -0.03 & -0.02 & 0.02 & 6.97 & 0.36 \\
\hline Mercury & -0.07 & 0.04 & 0.27 & 0.05 & -0.08 & -0.05 & 0.08 & -0.09 & 4.90 & 5.39 \\
\hline Poly & 0.06 & 0.04 & 0.18 & 0.15 & $-0.14^{\star}$ & $0.09 *$ & -0.01 & -0.02 & 7.36 & 6.32 \\
\hline Prestar & 0.18 & 0.01 & 0.22 & 0.11 & -0.08 & -0.09 & 0.01 & 0.01 & 2.40 & 3.02 \\
\hline Hil & 0.19 & $0.21^{*}$ & $0.21^{*}$ & $0.04^{*}$ & -0.03 & 0.09 & 0.03 & -0.08 & $10.06^{a}$ & 3.28 \\
\hline Super & 0.07 & -0.03 & 0.13 & 0.08 & -0.08 & -0.09 & 0.01 & 0.01 & 6.71 & 3.02 \\
\hline Setegap & -0.01 & 0.10 & 0.15 & 0.09 & -0.04 & 0.02 & 0.03 & -0.04 & 3.36 & 0.75 \\
\hline Ken & -0.11 & 0.05 & -0.01 & 0.19 & 0.07 & 0.08 & 0.04 & -0.10 & 4.15 & 4.65 \\
\hline Magna & 0.09 & -0.08 & 0.21 & 0.10 & 0.01 & -0.03 & -0.03 & 0.07 & 5.76 & 1.20 \\
\hline YCS & 0.07 & 0.15 & 0.18 & -0.01 & $-0.35^{\star \star}$ & $0.14^{\star *}$ & $-0.03^{\star \star}$ & $0.02^{* *}$ & 4.90 & $30.43^{b}$ \\
\hline Crest & 0.09 & -0.10 & 0.18 & 0.06 & -0.03 & 0.14 & 0.07 & 0.01 & 4.44 & 5.11 \\
\hline Eden & -0.04 & -0.03 & 0.19 & 0.04 & -0.12 & 0.06 & -0.02 & -0.11 & 3.43 & 6.36 \\
\hline Fitters & 0.08 & 0.06 & 0.16 & 0.18 & -0.09 & 0.12 & -0.11 & 0.01 & 5.52 & 7.78 \\
\hline Ganad & 0.04 & -0.15 & 0.16 & 0.13 & -0.03 & -0.02 & -0.16 & -0.01 & 5.39 & 5.38 \\
\hline
\end{tabular}




\begin{tabular}{|l|r|r|r|r|r|r|r|r|r|r|}
\hline Haio & 0.00 & -0.06 & 0.10 & 0.16 & 0.11 & 0.10 & 0.04 & -0.01 & 3.06 & 4.80 \\
\hline Hexagon & 0.07 & -0.06 & 0.04 & -0.02 & -0.02 & -0.11 & -0.09 & 0.02 & 0.83 & 4.56 \\
\hline Natwide & 0.05 & -0.19 & 0.10 & 0.18 & 0.01 & 0.16 & -0.01 & -0.06 & 6.56 & 6.00 \\
\hline Posim & 0.05 & -0.19 & 0.19 & 0.15 & 0.03 & 0.03 & -0.05 & -0.08 & 7.93 & 2.26 \\
\hline Suiwah & 0.14 & -0.01 & 0.18 & 0.15 & $0.28^{\star *}$ & $0.19^{\star *}$ & $0.13^{\star *}$ & $0.11^{\star *}$ & 6.13 & $29.97^{\mathrm{b}}$ \\
\hline Juan & -0.08 & 0.21 & 0.02 & 0.21 & -0.06 & 0.05 & -0.07 & 0.05 & 7.65 & 2.99 \\
\hline KLCl-2 $^{\text {nd }}$ & -0.13 & 0.04 & $0.35^{\star *}$ & $-0.15^{\star \star}$ & 0.05 & -0.03 & -0.04 & -0.09 & $13.53^{\mathrm{b}}$ & 2.73 \\
\hline
\end{tabular}

${ }^{*}$ Tolak hipotesis nol pada tingkat signifikansi $5 \%$ a Tolak hipotesis nol pada tingkat signifikansi $5 \%$

**Tolak hipotesis nol pada tingkat signifikansi $1 \%$ ' ${ }^{\text {}}$ Tolak hipotesis nol pada tingkat signifikansi $1 \%$

\section{Hasil Tes Run}

Tabel 5 menunjukkan jumlah dan persentase perubahan harga yang signifikan (maknanya menunjukkan perubahan harga tidak acak) setiap sektor menurut hasil tes run. Untuk periode I, pada tingkat signifikansi 5 persen, 5 persen dari saham barang industri mempunyai perubahan harga yang tidak acak. Pada tingkat signifikansi 1 persen, 11 persen dari saham barang industri mempunyai perubahan harga yang tidak acak secara signifikan. Sedangkan saham-saham dari sektor barang konsumsi, bangunan, dan perdagangan tidak satupun saham yang perubahan harganya tidak acak baik pada tingkat signifikansi 5 persen maupun 1 persen.

Untuk periode II, pada tingkat signifikansi 5 persen, 5 persen dari saham barang industri mempunyai perubahan harga yang tidak acak secara signifikan. Pada tingkat signifikansi 1 persen, 25 persen dari saham bangunan mempunyai perubahan harga yang tidak acak secara signifikan. Saham-saham dari sektor barang konsumsi dan perdagangan tidak satupun saham yang perubahan harganya tidak acak baik pada tingkat signifikansi 5 persen maupun 1 persen. Sedangkan indeks komposit papan kedua BSKL mempunyai perubahan indeks yang tidak acak pada tingkat signifikansi 1 persen pada periode II ini.

Tabel 5. Jumlah dan persentase saham setiap sektor dengan perubahan tidak acak pada tingkat signifikansi 5 dan 1 persen untuk periode I dan II

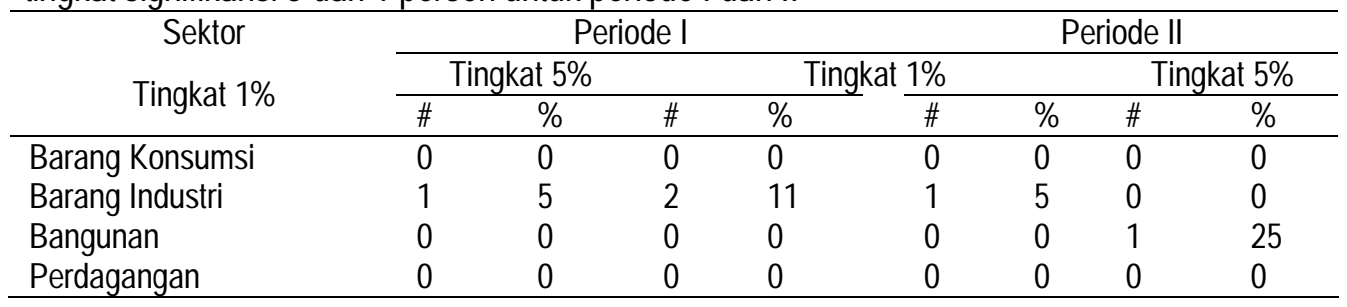


Tabel 6 menunjukkan hasil tes run untuk 40 saham di Papan Kedua BSKL terpilih dalam penelitian ini. Untuk periode I hanya ada 3 saham saja dari saham-saham tersebut menunjukkan perbedaan yang signifikan di antara jumlah jumlah run riil dengan jumlah run yang diharapkan. Ketiga saham tersebut adalah saham Daiboci berbeda secara signifikan pada tingkat signifikansi 5 persen, saham Kossan dan saham Prestar berbeda secara signifikan pada tingkat signifikansi 1 persen. Ini bermakna 7.5 persen dari saham-saham yang terdaftar di Papan Kedua BSKL menunjukkan kelainan dari hipotesis pasar efisien (HPE) bentuk lemah selama terjadi krisis ekonomi di Malaysia.

Pada periode II juga hanya ada 2 saham saja dari saham-saham di Papan Kedua BSKL yang menunjukkan perbedaan yang signifikan di antara jumlah run riil dengan jumlah run yang diharapkan, yaitu saham Ajiya signifikan berbeda pada tingkat signifikansi 5 persen dan saham YCS signifikan berbeda pada tingkat signifikansi 1 persen. Sedangkan indeks komposit papan kedua BSKL berbeda secara signifikan pada tingkat signifikansi 1 persen. Hasil ini bermakna bahwa 5 persen dari sahamsaham yang terdaftar di Papan Kedua BSKL dan indeks kompositnya menunjukkan kelainan dari HPE setelah terjadi krisis ekonomi.

Jika dilihat dari perbandingan jumlah keseluruhan run riil dan jumlah run yang diharapkan saham-saham tersebut, pada periode I terdapat 9 dari 40 saham mempunyai jumlah run riil lebih dari run yang diharapkan, tetapi kedua jumlah run tersebut tidak berbeda secara signifikan. Kesembilan saham tersebut yaitu saham Pohmay, saham Ajiya, saham Bright, saham Belton, saham KKB, saham Lsteel, saham Trutech, saham Mercury, dan saham Haio. Sedangkan pada periode II tidak satupun saham-saham tersebut yang mempunyai jumlah run riil lebih dari run yang diharapkan.

Tabel 6. Hasil tes run untuk periode I dan periode II

\begin{tabular}{|l|c|c|c|c|r|c|c|c|}
\hline \multicolumn{5}{|c|}{ Periode I ( $\mathbf{n}=\mathbf{7 8})$} & \multicolumn{4}{c|}{ Periode II $(\mathbf{n}=\mathbf{2 0 7})$} \\
\hline Saham & Run & Run & Nilai & Signifikan & Run & Run & Nilai & Signifikan \\
\hline & riil & diharapkan & Z & $(2$ ekor) & riil & diharapkan & Z & (2 ekor) \\
\hline Chewaah & 41 & 44.05 & 0.33 & 0.75 & 99 & 125.59 & -0.15 & 0.88 \\
\hline Hingyap & 34 & 41.69 & -1.32 & 0.19 & 101 & 124.29 & -0.48 & 0.63 \\
\hline Bonia & 37 & 43.67 & -0.55 & 0.59 & 87 & 121.55 & -1.53 & 0.13 \\
\hline Pohmay & 44 & 40.97 & 0.94 & 0.35 & 105 & 115.11 & 0.19 & 0.85 \\
\hline Rex & 31 & 39.89 & -1.83 & 0.07 & 107 & 118.8 & 0.37 & 0.72 \\
\hline Sinmah & 39 & 43.08 & -0.21 & 0.84 & 90 & 114.69 & -1.51 & 0.13 \\
\hline Tcguan & 38 & 48.67 & -0.41 & 0.69 & 92 & 139.98 & -0.45 & 0.65 \\
\hline
\end{tabular}




\begin{tabular}{|c|c|c|c|c|c|c|c|c|}
\hline Ajija & 45 & 42.67 & 1.31 & 0.19 & 86 & 132.95 & $-2.19^{*}$ & $0.03^{*}$ \\
\hline Belton & 41 & 40.97 & 0.45 & 0.65 & 113 & 114.45 & 1.27 & 0.21 \\
\hline Big & 33 & 41.69 & -1.58 & 0.12 & 94 & 119.67 & -1.46 & 0.14 \\
\hline Bright & 38 & 37.59 & -0.32 & 0.75 & 107 & 111.59 & 1.02 & 0.31 \\
\hline Daiboci & 31 & 46.67 & $-2.05^{\star}$ & $0.04^{*}$ & 106 & 120.68 & 0.25 & 0.80 \\
\hline Pahanco & 39 & 44.62 & -0.18 & 0.86 & 98 & 125.03 & -0.89 & 0.37 \\
\hline Harvest & 37 & 42.77 & -0.60 & 0.55 & 98 & 133.51 & -0.79 & 0.43 \\
\hline KKB & 43 & 41.74 & 0.79 & 0.43 & 102 & 124.87 & 0.23 & 0.82 \\
\hline KOA & 37 & 44.46 & -0.66 & 0.51 & 110 & 136.61 & 1.16 & 0.25 \\
\hline Kossan & 28 & 44.51 & $-2.69^{* *}$ & 0.01 ** & 110 & 122.32 & 0.77 & 0.44 \\
\hline Latex-X & 33 & 41.13 & -1.35 & 0.18 & 100 & 107.67 & 0.12 & 0.90 \\
\hline Lsteel & 45 & 39.89 & 1.14 & 0.25 & 87 & 128.5 & -1.73 & 0.08 \\
\hline Lysaght & 37 & 40.67 & -0.55 & 0.59 & 106 & 129.91 & 0.50 & 0.62 \\
\hline Trutech & 37 & 36.97 & -0.11 & 0.92 & 99 & 118.57 & -0.21 & 0.84 \\
\hline Mercury & 45 & 43.46 & 1.14 & 0.25 & 87 & 128.49 & -1.73 & 0.08 \\
\hline Poly & 37 & 39.54 & -0.32 & 0.75 & 107 & 113.76 & 0.73 & 0.46 \\
\hline Prestar & 27 & 45.51 & $-2.96^{\star \star}$ & 0.00 ** & 89 & 137.71 & -1.43 & 0.15 \\
\hline Hil & 37 & 39.54 & -0.41 & 0.68 & 108 & 118.69 & 0.83 & 0.41 \\
\hline Super & 35 & 39.44 & -0.60 & 0.55 & 89 & 117.48 & -1.43 & 0.15 \\
\hline Setegap & 35 & 38.15 & -0.69 & 0.25 & 110 & 112.21 & 0.92 & 0.36 \\
\hline Ken & 36 & 45.89 & -0.86 & 0.39 & 96 & 123.91 & -0.53 & 0.60 \\
\hline Magna & 38 & 42.05 & -0.32 & 0.75 & 92 & 128.15 & -1.41 & 0.16 \\
\hline YCS & 33 & 47.59 & -0.83 & 0.40 & 74 & 136.86 & $-3.35^{\star *}$ & $0.00^{\star \star}$ \\
\hline Crest & 37 & 40.46 & -0.49 & 0.63 & 107 & 119.38 & 0.73 & 0.46 \\
\hline Eden & 37 & 39.44 & -0.11 & 0.92 & 102 & 124.46 & 0.17 & 0.87 \\
\hline \begin{tabular}{|l|} 
Fitters \\
\end{tabular} & 41 & 44.05 & -0.23 & 0.82 & 93 & 125.44 & -1.23 & 0.22 \\
\hline Ganad & 41 & 42.05 & 0.28 & 0.78 & 96 & 123.13 & -0.53 & 0.60 \\
\hline \begin{tabular}{|l} 
Haio \\
\end{tabular} & 42 & 40.67 & 0.48 & 0.63 & 105 & 114.53 & 0.86 & 0.93 \\
\hline Hexagon & 38 & 44.62 & -0.37 & 0.71 & 99 & 125.19 & -0.74 & 0.46 \\
\hline \begin{tabular}{|l|} 
Natwide \\
\end{tabular} & 42 & 46.36 & 0.61 & 0.54 & 100 & 132.42 & -0.01 & 1.00 \\
\hline Posim & 37 & 41.13 & -0.22 & 0.82 & 91 & 120.82 & -1.78 & 0.08 \\
\hline Suiwah & 40 & 43.44 & 0.01 & 1.00 & 92 & 117.71 & -1.61 & 0.11 \\
\hline Juan & 43 & 43.67 & 0.79 & 0.43 & 112 & 120.71 & 1.05 & 0.30 \\
\hline KLCl-2nd & 38 & 34.82 & -0.32 & 0.75 & 84 & 103.69 & $-2.59^{* *}$ & $0.01^{* *}$ \\
\hline
\end{tabular}

Catatan: * Tolak hipotesis nol pada tingkat signifikansi 5 persen

** Tolak hipotesis nol pada tingkat signifikansi 1 persen 


\section{Hasil Tes Akar Unit}

Tabel 7 menunjukkan hasil tes akar unit tahap level bagi kedua periode analisis. Dari hasil tahap level tersebut diperoleh bahwa hipotesis nol yang menyatakan perubahan harga saham-saham papan kedua BSKL adalah fluktuatif (unstationary) ditolak pada tingkat signifikansi 1 persen. Ini artinya bahwa aliran perubahan harga saham sampel memperlihatkan adanya kestabilan (stationary). Kestabilan aliran perubahan harga saham ini mendukung hasil tes korelasi seri dan tes run sebelumnya bahwa pasar saham di Papan Kedua Bursa Saham Kuala Lumpur adalah efisien dalam bentuk lemah.

\section{KESIMPULAN DAN IMPLIKASI}

Menurut hasil tes korelasi seri untuk periode I (waktu selama krisis ekonomi) dan periode II (waktu setelah krisis ekonomi) hanya sebagian kecil saja saham-saham yang menunjukkan koefisien korelasi yang signifikan berbeda dengan nol. Ini berarti bahwa sebagian kecil sahamsaham yang terdaftar di Papan Kedua BSKL tidak mengikuti hipotesis pasar efisien (HPE) bentuk lemah. Saham-saham bersangkutan masih menunjukkan keadaan saling bergantung antara perubahan harga waktu lalu dengan waktu akan datang, terutamanya pada periode II (waktu setelah krisis ekonomi). Namun hasil tes korelasi seri ini, secara umum, mendukung hipotesis pasar efisien bentuk lemah bagi saham-saham di Papan Kedua BSKL.

Jika dilihat dari hasil tes run, secara rata-rata untuk periode I dan periode II sebagian besar saham menunjukkan perubahan harga yang acak. Hanya sebagian kecil saja saham-saham tersebut menunjukkan perubahan yang tidak acak. Hal ini berarti sebagian besar saham-saham yang terdaftar di Papan Kedua BSKL mendukung hipotesis.

Tabel 7. Hasil Tes Akar Unit Untuk Periode I Dan Periode II

\begin{tabular}{|l|c|c|c|c|c|c|c|c|c|c|}
\hline \multirow{2}{*}{ Saham } & \multicolumn{9}{|c|}{ Periode I $(\mathbf{n}=\mathbf{7 8})$} & \multicolumn{5}{c|}{ Periode II $(\mathbf{n}=\mathbf{2 0 7})$} \\
\cline { 2 - 12 } & $\mathrm{b}$ & $\mathrm{R}$ & t-hitung & $\mathrm{t}-\mathrm{ADF}$ & $\mathrm{D}-\mathrm{W}$ & $\mathrm{b}$ & $\mathrm{R}$ & $\mathrm{t}$-hitung & t-ADF & D-W \\
\hline Chewaah & -0.90 & 0.45 & $-5.76^{\star \star}$ & -2.96 & 1.99 & -0.88 & 0.46 & $-9.32^{\star \star}$ & -2.58 & 2.00 \\
\hline Hingyap & -1.03 & 0.52 & $-5.92^{\star \star}$ & -2.96 & 2.00 & -0.97 & 0.50 & $-9.80^{\star \star}$ & -2.58 & 2.00 \\
\hline Bonia & -0.90 & 0.45 & $-5.75^{\star \star}$ & -2.96 & 1.99 & -0.90 & 0.44 & $-9.77^{\star \star}$ & -2.58 & 2.00 \\
\hline Pohmay & -0.90 & 0.47 & $-6.33^{\star \star}$ & -2.96 & 1.97 & -1.04 & 0.57 & $-9.65^{\star \star}$ & -2.58 & 1.98 \\
\hline Rex & -1.13 & 0.49 & $-5.19^{\star \star}$ & -2.96 & 2.02 & -1.10 & 0.53 & $-10.83^{\star \star}$ & -2.58 & 1.98 \\
\hline Sinmah & 0.75 & 0.40 & $-5.06^{\star \star}$ & -2.96 & 2.01 & -0.93 & 0.46 & $-9.71^{\star \star}$ & -2.58 & 1.99 \\
\hline Tcguan & -0.80 & 0.38 & $-5.50^{\star \star}$ & -2.96 & 1.96 & -1.09 & 0.62 & $-10.10^{\star \star}$ & -2.58 & 1.96 \\
\hline
\end{tabular}




\begin{tabular}{|c|c|c|c|c|c|c|c|c|c|c|}
\hline Ajiya & -0.99 & 0.50 & $-5.95^{\star \star}$ & -2.96 & 2.00 & -0.95 & 0.50 & $-9.58 * *$ & -2.58 & 1.99 \\
\hline Belton & -0.99 & 0.45 & $-6.34^{\star *}$ & -2.96 & 1.94 & -0.99 & 0.47 & $-10.31^{* *}$ & -2.58 & 2.00 \\
\hline Big & -0.86 & 0.46 & $-5.43^{\star *}$ & -2.96 & 2.01 & -1.03 & 0.52 & $-10.16^{* *}$ & -2.58 & 1.99 \\
\hline Bright & -0.90 & 0.52 & $-5.40^{* *}$ & -2.96 & 2.03 & -0.99 & 0.50 & $-10.09 * *$ & -2.58 & 2.00 \\
\hline Daiboci & -0.83 & 0.38 & $-5.73^{\star *}$ & -2.96 & 1.98 & -0.98 & 0.53 & $-9.57^{\star *}$ & -2.58 & 1.98 \\
\hline Pahanco & -1.02 & 0.50 & $-6.17^{* *}$ & -2.96 & 1.99 & -1.22 & 0.54 & $-12.03^{* \star}$ & -2.58 & 2.03 \\
\hline Harvest & -1.03 & 0.49 & $-6.27^{\star *}$ & -2.96 & 1.99 & -0.92 & 0.45 & $-9.73^{\star *}$ & -2.58 & 1.99 \\
\hline KKB & -1.08 & 0.47 & $-7.08^{\star *}$ & -2.96 & 1.95 & -1.11 & 0.56 & $-10.62^{* *}$ & -2.58 & 2.00 \\
\hline KOA & -1.03 & 0.46 & $-6.63^{\star *}$ & -2.96 & 1.95 & -0.94 & 0.50 & $-9.45^{\star \star}$ & -2.58 & 1.97 \\
\hline Kossan & -0.80 & 0.62 & $-4.47^{* *}$ & -2.96 & 2.06 & -1.11 & 0.55 & $-10.71^{* *}$ & -2.58 & 1.99 \\
\hline Latex-X & -0.82 & 0.39 & $-5.54^{\star *}$ & -2.96 & 1.99 & -0.84 & 0.58 & $-8.78^{\star \star}$ & -2.58 & 2.00 \\
\hline Lsteel & -0.82 & 0.53 & $-5.91^{* *}$ & -2.96 & 2.02 & -1.14 & 0.54 & $-11.06^{* *}$ & -2.58 & 1.99 \\
\hline Lysaght & -0.90 & 0.41 & $-6.03^{\star *}$ & -2.96 & 1.93 & -1.02 & 0.59 & $-9.56^{\star *}$ & -2.58 & 1.97 \\
\hline Trutech & -0.91 & 0.46 & $-6.02^{\star \star}$ & -2.96 & 1.98 & -1.04 & 0.50 & $-10.41^{\star *}$ & -2.58 & 2.00 \\
\hline Mercury & -1.02 & 0.44 & $-5.87^{\star *}$ & -2.96 & 1.98 & -1.13 & 0.54 & $-11.06^{* *}$ & -2.58 & 1.99 \\
\hline Poly & -0.91 & 0.47 & $-5.65^{\star *}$ & -2.96 & 2.01 & -1.05 & 0.57 & $-9.94^{\star *}$ & -2.58 & 2.00 \\
\hline Prestar & -0.83 & 0.41 & $-5.57^{\star *}$ & -2.96 & 1.99 & -1.17 & 0.54 & $-11.39 * *$ & -2.58 & 2.00 \\
\hline Hil & -0.66 & 0.42 & $-4.50^{\star *}$ & -2.96 & 2.04 & -0.94 & 0.51 & $-9.38^{\star \star}$ & -2.58 & 2.00 \\
\hline Super & -0.90 & 0.53 & $-5.95^{\star *}$ & -2.96 & 2.02 & -1.07 & 0.54 & $-10.39 * *$ & -2.58 & 2.00 \\
\hline Setegap & -0.90 & 0.51 & $-5.43^{\star *}$ & -2.96 & 2.02 & -1.02 & 0.52 & $-10.07^{* *}$ & -2.58 & 1.99 \\
\hline Ken & -1.07 & 0.55 & $-6.04^{\star *}$ & -2.96 & 1.99 & -0.86 & 0.47 & $-9.02^{\star \star}$ & -2.58 & 2.00 \\
\hline Magna & -0.75 & 0.49 & -3.90 ** & -2.96 & 2.02 & -1.01 & 0.49 & $-10.26^{\star \star}$ & -2.58 & 2.00 \\
\hline YCS & -0.80 & 0.48 & -4.99 ** & -2.96 & 2.05 & -1.31 & 0.67 & $-11.33^{\star *}$ & -2.58 & 2.00 \\
\hline Crest & -1.01 & 0.46 & $-6.39 * *$ & -2.96 & 1.95 & -0.88 & 0.52 & $-8.86^{\star \star}$ & -2.58 & 2.02 \\
\hline Eden & -1.08 & 0.52 & $-6.32^{\star *}$ & -2.96 & 1.98 & -1.07 & 0.56 & $-10.19^{* \star}$ & -2.58 & 2.00 \\
\hline Fitters & -0.87 & 0.47 & $-5.53^{\star *}$ & -2.96 & 2.00 & -0.97 & 0.55 & $-9.40^{\star \star}$ & -2.58 & 1.97 \\
\hline Ganad & -1.11 & 0.49 & $-6.83^{\star *}$ & -2.96 & 1.93 & -1.05 & 0.51 & $-10.37^{\star \star}$ & -2.58 & 2.00 \\
\hline Haio & -1.10 & 0.52 & $-6.96^{* *}$ & -2.96 & 1.99 & -0.81 & 0.45 & $-8.69 * \star$ & -2.58 & 2.00 \\
\hline Hexagon & -1.00 & 0.47 & $-6.22^{\star *}$ & -2.96 & 2.00 & -1.13 & 0.51 & $-11.39 * \star$ & -2.58 & 2.02 \\
\hline Natwide & -1.14 & 0.49 & $-7.12^{\star \star}$ & -2.96 & 1.95 & -0.83 & 0.52 & $-8.51^{\star \star}$ & -2.58 & 2.00 \\
\hline Posim & -1.14 & 0.50 & $-7.15^{\star *}$ & -2.96 & 1.92 & -0.94 & 0.49 & $-9.60 * \star$ & -2.58 & 1.98 \\
\hline Suiwah & -0.89 & 0.44 & $-5.77^{\star *}$ & -2.96 & 1.97 & -0.63 & 0.37 & $-7.54^{\star *}$ & -2.58 & 2.01 \\
\hline Juan & -0.87 & 0.56 & $-5.08^{* *}$ & -2.96 & 2.01 & -1.02 & 0.53 & $-9.94^{\star *}$ & -2.58 & 1.99 \\
\hline $\mathrm{KLCl}-2 \mathrm{nd}$ & -1.11 & 0.57 & $-6.22^{\star *}$ & -2.96 & 2.02 & -0.97 & 0.47 & $-10.14^{\star \star}$ & -2.58 & 2.00 \\
\hline
\end{tabular}

Catatan: * Tolak hipotesis nol pada tingkat signifikansi 5 persen

** Tolak hipotesis nol pada tingkat signifikansi 1 persen pasar efisien bentuk lemah baik periode selama krisis (periode I) maupun periode setelah krisis (periode II). 
Menurut hasil tes akar unit menunjukkan bahwa semua harga saham di Papan Kedua BSKL yang menjadi sampel mempunyai kestabilan (stationary) dalam aliran perubahannya. Hasil tes akar unit ini mendukung hasil tes korelasi seri dan tes run. Dari ketiga hasil penelitian menunjukkan bahwa secara umumnya saham-saham yang terdaftar di Papan Kedua BSKL mendukung hipotesis pasar efisien bentuk lemah untuk periode selama krisis ataupun periode setelah krisis ekonomi di Malaysia.

Penelitian hipotesis pasar efisien bentuk lemah di Papan Kedua BSKL belum banyak dilakukan. Oleh karena itu penelitian-penelitian untuk masa yang akan datang perlu dilakukan dengan menambah jumlah sampel saham dan menggunakan berbagai model yang lebih canggih untuk menemukan hasil yang semakin tepat.

\section{DAFTAR PUSTAKA}

Barnes, P. 1986. Thin trading and stock market efficiency: The case of the Kuala Lumpur Stock Exchange. Journal of Business Finance \& Accounting 13 (4): 609-617.

Berkman, N. 1978 (Sept.-Okt.). A primer on random walks in the stock market. New England Economic Review: 32-49.

Cheng, K. 1978. The random walk hypothesis: An empirical test with Malaysian share price. Ocassional Paper. Faculty of Economics and Business Management. Universiti Kebangsaan Malaysia.

D'Ambrosio, C.A. 1980. Random walk and the stock exchange of Singapore. Financial Review 15-12: 1-12.

Dickey, D.A. \& Fuller, W.A. 1981. Likelihood ratio statistics for autoregressive time series with a unit root. Econometrica 49: 1057-1072.

Dockery, D. Vergari, D. \& Vergari, F. 2001. Explaining the behaviour of stock prices in an emerging market: An empirical analysis of the Greek Stock Market. Managerial Finance 27. 1/2: 82-96.

Fama, E.F. 1965. The behavior of stock-market prices. Journal of Business 38-1: 34-105

Fama, E.F. \& Blume, M.E. 1966. Filter rules and stock market trading. Journal of Business: 226-241.

Fama, E.F. 1970. Efficient capital market: A review of an empirical work. Journal of Finance 25: 383-417. 
Fama, E.F. Fisher, L. Jensen, M.C. \& R.Roll. 1969. The adjustment of stock prices to new information. International Economic Review 10: 1-21.

Fielitz, D.B.1974. The random walk model of stock market prices: A review. The Wall Street Review of Books: 1-31.

Haugen, R.A. 2001. Modern Investment Theory. Fifth edition. New Jersey. Prentice Hall.

Kleiman, R.T. Payne, J.E. \& Sahu, A.P. 2002. Random walks and market efficiency, evidence from international real estate markets. Journal of Economic Review 24.3: 279-298.

Lim, T.L. 1981. The efficient market hypothesis and share price behaviour on the KLSE. Dalam Yong, O. \& Ibrahim, I. Understanding the behavioural patterns of stock prices: A collection of readings on selected far eastern stock markets. Leeds Publications. Kuala Lumpur.

Nasir, A.M. \& Mohamad, S. 1993. The Efficiency of the Kuala Lumpur Stock Exchange: A Collection of Empirical Findings. Penerbit Universiti Pertanian Malaysia.

Nassir, M.L. 1983. A Study of market efficiency and risk return relationship in the Malaysian Capital Market. Ph.D. Disertation. Katholieke University of Leuven. Belgium.

Ojah, K. \& Karemera, D. 1999. Random walks and market efficiency test of Latin American Emerging Equity Markets: A revisit. The Financial Review 34: 57-72.

Yong, 0.1987. Market efficiency (weak-form) test of the Malaysian Stock Exchange. Business Finance in Less Developed Capital Markets: 137-167.

Yong, O.1997. Intrduction to Financial Theory. Kuala Lumpur: Dewan Bahasa dan Pustaka.

Wong, K.A. \& Kwong, K.S. 1984. The behaviour of Hongkong Stock Prices. Dalam Yong, O. \& Ibrahim, I. Understanding the behavioural patterns of stock prices: A collection of readings on selected far eastern stock markets. Kuala Lumpur: Leeds Publications. 